\title{
Steering of Educational Processes in a Digital Medium Environment
}

\author{
By Jesper Tække and Michael Paulsen
}

Centre for Internet Research, Aarhus University, Denmark

Department of Learning and Philosophy Aalborg University, Denmark

\begin{abstract}
This paper is about challenges to steering and leadership of educational interaction in classrooms provided by the new medium environment that comes with digital media. In the new medium environment, the old way of steering what is going on in the classroom appears not to work since it was developed in the image of the industrial society and based on a closed classroom. Now with the digital media and wireless networks the classroom is opened and the old way of organizing teaching has become inadequate: The students are disturbed by the new media, instead of learning through them. Inspired by systems theory we outline a more adequate way of teaching in the new medium environment - a teaching that can manage the new situation and use the new possibilities provided by the digital media. The argumentation builds on empirical findings from the action research project Socio Media Education (SME), which has worked with possibilities and problems in regard to the digital medium revolution's disruption of the Danish upper secondary school (Takke E Paulsen 2015a, b, 2014, 2013a, b, c, 2012).
\end{abstract}

url:

\section{Introduction}

According to Luhmann (2006), the school works as an organisational system with management and decisions, while the educational processes in the classrooms, because of its enormous complexity runs as an interaction system. The teacher leads the educational process, writes on the blackboard, asks others, gets answers and through different methodologies steers as though it is possible. But Luhmann (2006: 144) pinpoints that teaching conducted in the form of interaction neither can be understood as steered by rules, nor as a causally shaped course of means and ends - or be in any way calculated in advance. Instead, Luhmann believes the form of interaction systems serves the installation of structural indeterminacy in the education system, where the pedagogical intention constantly has to be re-specified. However, this form of teaching, which has lasted for centuries, more or less successfully, under different pedagogies and discourses of discipline, has rested on a number of preconditions implemented in the physical architecture and medium technology. ${ }^{\mathrm{i}}$ With the digital medium environment the structural indeterminacy have taken new directions leaving the teacher in a new situation with students participating in interactions, on Facebook and other social media, in parallel with the educational interaction (Tække \& Paulsen 2013a, b, c, 2012). Before, the teacher's point of view was protected by the walls against other observer's potentially differing meanings about his ways of seeing things (Luhmann 2006: 71). Also, the walls protected against distractions from the outside world, like interference from people joining or leaving and made it 
possible for the educational interaction to decide its own theme, as well as when to begin, change, or drop a theme (ibid: 131).

Now the medium environment has changed, the classroom has been opened up and in the surrounding world we see new forms of knowledge work, for instance, conceptualised as produsage (Bruns 2008) in convergence and participation cultures characterised by shaping, sharing, reframing, remixing and appropriation (Jenkins 2013, 2008, 2006). In this new medium environment, it is neither adequate to prohibit nor to ignore the new media. The students must learn to organise, interact, search, network etc. in the current environment, while the teachers must try to steer and lead in new ways that are appropriate to the new information- and interaction situations. In this article we will scrutinize, discuss and theorise these new challenges.

\section{The Old, Closed Classroom}

The school has for centuries been based as a social system that processes in a closed room: "The interaction takes place in a closed room that are not public, so that distraction from the outside world can be minimized" (Luhmann 2006: 131). ${ }^{\text {ii }}$ So it is, if not a precondition as a starting condition, then at least a relationship which for centuries has been the case, that the four walls have protected what was going on in class: "Especially ensures the spatial secretion of education that the education system can control its own thematic, and decide for itself when to begin, alternating or quit themes" (Luhmann 2006: 132). The classroom has had a tight and insulating membrane around it and the exchange relationship between the classroom's interaction system and the outside world has been conditioned in time and space by law and school organisation and steered by the teacher as a gatekeeper. The teacher has been the authority, who has been able to be the final judge over right and wrong, good and evil. This form of teaching occurred after the introduction of the printing technology. In Denmark

Figure 1. The classroom with a an isolating membrane, the situation before digital media.

\section{Friends}

Film and mass media

Politicians

Games

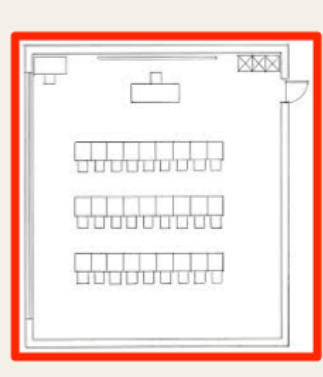

hobby all children had to go to school with the Education Act of 1814. Through printed textbooks produced centrally the state power began to influence students all over Denmark. In the meantime, teaching was still led by the specific teacher's interpretation of the text both in relation to opinion and to understanding. With the analogue electronic media the teacher, for example, could bring a tape recorder so that students could hear a real Englishman speak English. Later, images and text could be shown with an overhead projector. With the

introduction of the copying machine the teacher could make copies and had a greater impact on the curriculum (Tække \& Paulsen 2015a). Common to the two media periods, however, was that teaching was conducted as echo space-teaching, so that the teacher wrote something from the textbook on the blackboard and students wrote down in their notebooks what the teacher written, which they could subsequently be examined in. There was a very strong line of demarcation in the form of the nonpermeable membrane: the four walls between the classroom's interaction system and the outside world. On the external side of the membrane, at home, the students were left to their close relationships, the strong bonds consisting of family and acquaintances giving birth to the concept of opportunity inequality, and negative social heritage respectively. The education community could not 
reach out and help students at home and many experienced a doxa discrepancy between home and school (ibid). Of course, the electronic mass media did soften this relationship by being generally cultivating when we look at the small homes. Their influence, however, was probably larger on norms in the classroom, changing the information situation so that the pupils now could know everything and also knew, that the teacher did not know everything, and could be wrong, while the teacher now had to act according to the knowledge that the pupils knew this. With the transparency provided by television corporal punishment was banned by law. iii In addition, it is still the case that the teacher with a group of students from literate homes dominate the educational community and condition it. Teachers naturally accept pupils with a dominant social origin who, through their receptions, attitudes, language codes, naturalness, elegance and personality, have a greater weight than students who communicate in other codes (Bourdieu 2000). Further, the fact is that the knowledge that can be obtained through the analogue electronic media is not enough when it comes to formal education where you cannot escape reading and writing: "The logical linking of pieces of information into large, complex, and connected treatises and theories is a feature of writing and print" (Meyrowitz 1985: 79). You can then add that this is the case whether it is on paper or online (on cyber).

Overall, when we focuses on leadership and steering of teaching, then the teacher loses some authority with the introduction of analogue electronic media, but is still protected by the dense membrane around the classroom. The teacher is not allowed to use physical force anymore but can still discipline and steer the direct exchanges between the classroom and the outside world.

\section{The Open Classroom}

With the introduction of digital media, installation of wireless networks and every student having their own personal laptop or tablet, we are in a new situation. The membrane between the classroom and the outside world has become porous and permeable to any kind of digitally mediated information and interaction. Now students can stay in contact with each other regardless of time and space. For example, we see love affairs, intrigues, or a nice talk about football continue into the teaching space and time. Students can also write about their teacher or the teaching. In addition, the control of the demarcation line is completely eroded - friends from other classes, parents, and all others can be contacted and even interfere. Students can watch other students pictures or other friends' pictures on Instagram or Facebook, buy clothes, watch movies, read the news, play games together or with others from around the world, or just with oneself etc. Attention is drawn away from the teaching and students, and teachers are ready to diagnose the students as addicts (Paulsen and Tække 2009). However, it seems more likely that the new information and interaction situations are experienced as socially ambivalent, since adequate norms are not socially developed (selected) yet (Tække and Paulsen 2010). According to international research, however, it seems as though teachers, if they use the new media in their teaching, can regain attention and commitment and even provide a better teaching than before (see research review in Tække and Paulsen 2013a). Nevertheless, the general reaction in the Danish educational institutions either is to prohibit or be indifferent with regard to the new media. This is a quite inappropriate response if the problem is a lack of social structures and norms. The new digital media creates a new kind of ether, a new possibility space for communication, which are colonized by social systems that produce and reproduce new structures and norms adequate to the new conditions. If these structures are not influenced and formed with the participation and leadership of teachers, it is hard to imagine that they could appropriately work together with teaching. To express this in another way, the teaching will proceed in a manner that is shaped by a previous medium situation and will thus be inadequate 
for the current media situation and not provide the students with the necessary reflexivity and literacy in relation to a social world, which for the most part are already digitally mediated.

\section{The Socio Media Education Experiment}

We have investigated the educational challenges and possibilities of the new media situation in an action reach project called the Socio Media Education experiment (the SME-project). In this project we have followed (and act upon) an upper secondary school class during its three years from 2011 to 2014 (Tække \& Paulsen 2015a, b, 2014, 2013a, b, c, 2012). In the project, we provided the teachers (and sometimes also the students) with "rules" (ideas, guidelines, knowledge, suggestions, questions, concepts, observations etc.) and the teachers made experiments and interventions based on interpretations of our suggestions in the form of actions that we documented (leading to new ideas, observations etc. communicated "back" to the teachers, and so on forming a circular feedback and feedward system between researchers and teachers pertubated ongoingly by the international research community on the on hand and the educational system on the other). ${ }^{\text {iv }}$ It was designed so that we as researchers introduced rules (etc.) for the teachers, in particular a ban against prohibition and ignorance in relation to any kind of media use. Instead, the teachers had to initialise reflexivity and use digital media within the teaching. On this basic condition, the teachers experimented through multiple actions, such as using Twitter during film watching and student presentations. Using Twitter and shared documents (google.doc), the teachers managed to capture the attention of the students again and to restructure the teaching. The efforts provided rearmament inside the schoolroom with digital text media, which provided a re-stabilization of the education system in spite of the porous membrane around the classroom. This is however only partly possible while some attention still leaked out of the room. On the other hand, we also saw an outgoing movement where the educational community was extended spatiotemporally through homework assistance and the organising and documentation during a study trip to Copenhagen. The teachers regained their power through better possibilities for monitoring, intervention, control, interpellation and facilitation. The better transparency provided by the digital media also let them get a better knowledge of the students and a better and more trustful relationship to them. However, the processes were mostly instructive, directive and encouraging, with little reflectivity being initiated. Also the outside of the distinction between the class and the surrounding world was still ignored.

\section{The Situation Outside School}

In the community outside school it has become the rule that one searches for information and works upon and combines what others have produced. According to Axel Bruns, our concept of production originates from the industrialisation and therefore gives a clear distinction between producer, distributor and consumer. This distinction is not adequate any longer since: 1 . Our access to information is no longer carried out from an information-push model, but rather from an information-pull model, as we are no longer limited to the mass media, which provides no feedback, 2. We now have access to the means to produce and distribute information ourselves, 3. The same technology that enables many-to-many communications and distribution of content can be used by ourselves in peer-to-peer communication, which allows us to organise in networks in relation to a variety of different shared projects, and 4 . In its digital form, content is quick and easy to share, modify, extend and recombine (Bruns 2008: 14-15). In such a medium environment, the student must not only be educated to become a consumer, but also be producer-user - one who practices produsage, as Bruns defines it. In such a society, the network or the creative community becomes the important focal point: "what the network model makes possible is the existence of a distributed but 
coordinated community, organised not according to the directions of a central authority to which all other nodes in the network are subordinate, but by the community's own protocols of interaction" (Bruns 2008: 15). In line with this, Tim Berners-Lee talks about intercreativity made possible through non-hierarchical many-to-many media through which people collaborate on the development and expansion of shared information resources of common interest (Bruns 2008: 16). The school should hopefully achieve a 'mode of production' that matches the one that takes place in contemporary society and not reproduce yesterday's now antiquated echo-room method of reproducing knowledge and its organisational mode of power and doxa (Tække \& Paulsen 2015a).

Jenkins (2013: 2) writes about a shift from distribution to circulation and a movement toward a participatory model of culture, in which we shape, share, reframe and remix media content. In this he highlights appropriation as: "The ability to meaningfully sample and remix media content" (Jenkins 2006: xiv). In comparison, a person was not assumed to be literate if he could read but not write in the era of the print community. Nowadays, we should not assume that someone possesses media literacy if they can consume but cannot express themselves in the new media (Jenkins 20o8: 176).

\section{Back to the SME Experiment}

Even though the educational community was restructured and relatively undisturbed because of the research design in the first year of the SME project, the view on learning and digital literacy stayed in the epochs before produsage and appropriation. The digital media were only used to create a renewed and reinforced attention on the activity in the classroom. In the meantime, the use of Twitter did not only increase the concentration around the educational topic, but also trained the students competencies in written interaction. From the second year of the project, the teachers also had to make contacts out of the classroom and include external resources, persons and networks in the teaching. From this time the students really did benefit from their many hours of academic interaction through Twitter. At this stage the students were able to use the digital media at such a level that they could make contact to resource persons outside the classroom, which on the one hand increased their attention towards the educational object to new heights, driven by their own engagement and motivation. On the other hand, this form of education seemingly brings them into a position of a producer, cultivating them to participation in networks, increasing their digital literacy and in this process also raising the quality of the teaching, bringing into it knowledge from key persons from different fields. In the meantime, this new form of teaching also means a new teacher role and practice bringing fourth the question about how the teacher can steer and lead this form of teaching.

\section{The Masterful Teacher}

Following Qvortrup (2013), we might get some answers that can help understand what the teacher can do to maintain the role as classroom leader in the new media environment. First of all, teachers must be experts in their teaching area, giving them academic authority. This must surely also apply to the use of the new digital media. Teachers must be able to go ahead and with knowledge of social media, digital search and source criticism, etc., to be able to help, qualify and stage communication in the classroom as well as out of it. In this regard, the concept of management of self-management seems to be useful. The idea is that the leader, is the leader of others self-leading or by others leading of others. The person who is the object of management decisions thereby also becomes the subject to management decisions. Systems theoretically, one can formulate it as a distinction between first 
order management decisions and second order management decisions (Qvortrup 2013). First order is a directive style: do this and that, while second-order sets goals and frames for the work process. For example, the teacher can provide tasks containing priorities for the switch and provide available network openings, i.e. find resource persons for the students and make appointments with them. The teacher contacts, for example, politicians, representatives of organisations, artists, foreigners, welfare recipients or networks of literary people, athletes, or anything that may be relevant to the class' current work. There is still a need for a decision hierarchy, where the teacher sets decision premises for students' decisions for working with the switch in and out of the class. The teacher can facilitate change, by being subject for management decisions, but only little management can be directive; management of self-management provides a much greater reduction of complexity than first order management (regarding Luhmann's concept of power see Tække 2010). The teacher can constructively influence the switch out of the classroom and into the classroom, the media and networks that are used, the type of project, and with regard to what kind of results the teacher wants. The teacher tolerates, so to speak the loss of control, but regains control with second-order decisions at a higher organisational level - much like with the group work, as already known, where power is also delegated out in trust, with a corresponding loss of direct control as a result.

\section{Power and Steering}

Luhmann (1979: 112) defines coercion as the counter concept to power. Using the distinction between power and coercion makes it possible to describe power as a communication code. The power code reduces social complexity by reducing double contingency in situations between power-holder and power-subject - both of them can see the advantages in coupling to the power medium. Coercion gives no alternative, but power does. In other words, the ability to reduce double contingency is lost when power turns into coercion. The advantage provided by the symbolic generalisation, where only the selectivity of the partner is guided, gets lost when power turns into coercion (ibid.). Therefore, power makes it probable that people freely select to do what others tell them to.

Coercion means that the advantage of the symbolic generalisation by the leading of the partner's selectivity is lost: the person exercising coercion must himself take over the burden of selection and decision, the reduction of complexity is not distributed but transferred to the person using coercion (ibid.). Coercion might be centralised in more simple systems while power is a condition for more complex systems. In the old, closed classroom processes, teaching ran (to begin with) more like a machine - the echo-room was designed more on the philosophy of coercion than on power. After the introduction of analogue electronic media, especially television, the situation were changed and, as mentioned above, a more democratic form of teaching saw the light, power became used more, for instance, in group-work, which can bee seen as a form of power chain. Power chains in organisations increase the scope of power to a degree that far surpasses what a single person would be able to perform (Luhmann 1979: 133, 1990: 161) ${ }^{\mathrm{v}}$. With a power chain we can see that A can have power over $\mathrm{B}, \mathrm{B}$ power over $\mathrm{C}$ etc. Thus, power is not a zero-sum game and in the new medium environment, with the open classroom, the complexity has grown extremely so that the education system must select not only power in favour of coercion, but also try to organise the educational processes as power chains including other nodes than the students and the teacher. In this way, the SME-classes were organised by their teachers in groups that were trusted to interact with an author, a school class from Germany, and representatives from their local business community.

When it comes to steering, Luhmann uses the concept of technology on the social level. In particular, this is in connection with management trying to minimise a specific difference between calculus and deviation, or between expectation and disappointment (Andersen \& Thygesen 2004). 
This could be certain teaching methods: You want the students to learn something specific and therefore use a specific teaching method (see Luhmann, 2006: 176, and Lars Qvortrup's introduction to the same pp. 16-18).

Luhmann (2007: 92) pinpoints Heinz von Foerster's distinction between trivial and nontrivial machines. Trivial machines are such devices based on a rule steering that always produces a certain result when fed with energy or information. If you give it another input, it works again and produces, if it has more features, a different result. Non-trivial machines, on the other hand, always ask themselves and use their own internal complexity to produce the output. There is a built-in selfreferential loop in non-trivial machines (ibid.). If a student, for example, gets a question, the student must ask herself, try to remember or reason out an answer, in contrast to a calculator that in a trivial way spits out a result. Luhmann points out that we often want the social and psychic machines to behave as trivial machines. We would like, for example, that the students understand and learn what they should in the same way and with the same examples as last year. We do, however, not master operationally closed machines in the same way as with the causally closed trivial machines. Yet, it is also essential to pinpoint, that in many cases we want students to learn to think critically for themselves, that is to become what they in a way already are: non-trivial machines. And in many cases we want teaching systems that ask questions without definite answers. And especially in the new digital age this becomes more important than ever because when almost all facts becomes searchable on the net it is not the exact answers that have core value, but interpretations and reinterpretations, connections and creativity, network and relations and the power of judgement. One could say that the shift to the new digital environment also demands a shift from treating students in many cases as trivial machines to helping them to be non-trivial (on a "higher level"). And this is also linked to the shift from first order management to the second order. Instead of using coercion or even simple power, and thus using technological assumptions treating the students as trivial machines, the teacher must try to create and steer educational valuable power chains between nontrivial machines, that is for instance between an author (who is by definition non-trivial) and the students engaging with real unpredictable questions in the dialogue with the author.

As with the subject of power, maybe steering, before in the closed classroom, inspired by the industrialisation, acted more toward students as though they were trivial machines than we should now in the opened classroom. Steering must be built into the learning processes in such a way, so the students can benefit from, and learn to navigate in the new medium environment. The teacher must develop a new teacher role that includes the construction of social networks that facilitate student activities so that they learn to act as producers in networks in order for them to both learn in regard to their subject and learn to steer themselves in the new spatiotemporal conditions. In such a world, students must have a learning milieu in which they can develop an internal complexity that matches the environment. But how can one more specifically regain control and keep the teachingdefining asymmetry between teacher and student?

\section{Steering in the New Medium Environment}

The problem teachers are facing is that digital media have a much smaller invariance than previous media such as overhead projectors, copiers, blackboards and books. They are all of these things at once and much more: they are storage, searching, copying, interaction medium etc., since they are part of an overall media matrix that, through the shared basic digital technology, provides unlimited translation, incorporation and integration between all known media genre and registers (see Finnemann 2005). This unlimitedness makes it impossible for the teacher, in the situation, to close the teaching operationally by a technical causal closure. This means that when a student writes 
something online, everybody else can observe it, mingle, find it via a search, send it to a third party, add music, etc. In addition, students can copy everything to their own online space, produced by everybody else. However, the question is whether closing down this unlimitedness would be absurd in a society that, in its knowledge production, is now characterised by produsage, remix, intercreativity, appropriation and a participatory culture and therefore cannot be limited.

If teachers and schools should not "close down" the Internet in the educational situations (which is most likely not only absurd but also impossibly for several reasons) they must (in one way or another) converge to the new (re)production practices (e.g. remix), which the literature describes is going on in the new medium environment and develop methods to organise, orchestrate and stage produsage, remix and appropriation.

A second order management could be to program the media, for instance, by writing assignments into shared documents with spaces for student responses (Tække \& Paulsen 2015a, b). This creates the opportunity for students to work simultaneously on the same document, and at the same time make it possible for the teacher from a

Figure 3. the classroom as an educational community and learning network

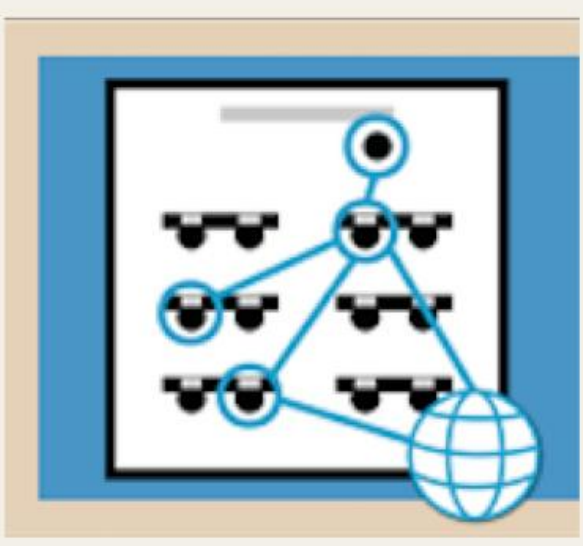

central level to follow the work and support it in the process with feedforward and feedback. Another example is to use specific hashtags for organising group work, which also makes it possible for the teacher to link to work. Students seek information online, contact networks, etc., while they use and report on the agreed hashtag. The teacher can also organise the contact in and out of class by steering the framework, for instance, via a requirement to source criticism and to which networks or persons the students must contact and interact with. In addition, the teacher

can incorporate decision premises with requirements for produsage and remix, such as disclosure of the sources remixed from, for example, other students' work found on the web. This will allow the teacher to support all stages of learning: search, source criticism, the use of already existing texts including quoting, using references, production of compilations and summaries, etc., and therefore what is understood by appropriation as distinct from plagiarism. Common to these activities and working methods are that they all take place in open networks organised and quasi-controlled from the inside by the teacher via decision premises and the ability to follow and connect to the process. The teacher-led educational community will, with the teacher as facilitator, and the one who set the frames, again act in accordance with the medium environment. Also, the teacher can intervene and provide coaching, feedback and assistance while students are at home after school using a medium like Twitter (Tække \& Paulsen 2013a, 2015a). 


\section{Conclusion}

The production method now referred to as produsage, remix and appropriation, sounds neither new, nor scary for a systems theorist, since we know that, from a systems theory perspective, that we do not start from scratch, but stand on the shoulders of our predecessors and their work. The social environment consists more in reproduction than in

Figure 4. The school class as an autopoietic system

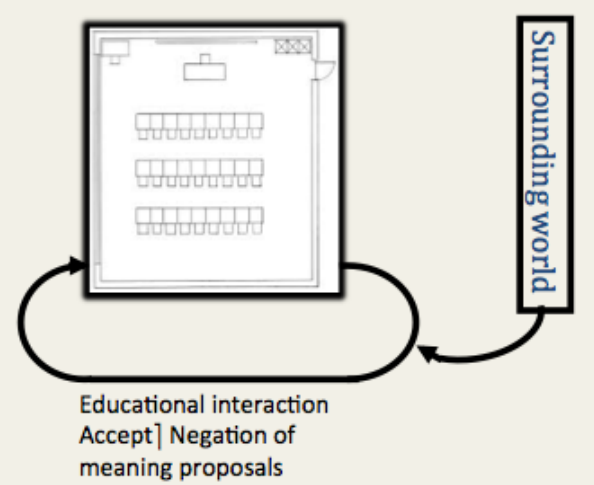
production, in the sense that the term structure in Luhmann's systems theory signifies what is expected. Nothing would be possible if everything had to be always new, in fact it is only a tiny part that is truly new, if anything at all. This always applies for autopoietic systems and not only for content production in scientific, educational, artistic, mass media systems, etc., but also when we look at an educational community in a classroom. Structures come into being through the processes that reproduce them, but processes need structures to proceed (Luhmann 1995). As the saying goes: systems must be changed from within. The processes may use the already available structures and slowly over time change the

structure piece by piece. If we see a class or the educatiuonal situation as such as an autopoietic selforganising interaction system, the teacher must seek to install decision premises that stimulate the formation of a border of meaning in the educational community for the students' interaction with each other, with external parties in a qualification and cultivation of the contacts within the class, and between its students and resource persons from the surrounding world. This corresponds to a conditioning of relationships, where the students' relationships to each other in and out of class are relation-related by the teacher (see Qvortrup 1998: 108 about relation-related). The relationship between the teacher and the students is related by the school and by their shared relation to the history of interaction consisting of accepted and rejected meaning proposals, which over time has produced the border of meaning in the class (see Luhmann 1995 about the concept of border of meaning). In the same way, the student's and teacher's relationships out of class to websites, networks and resource persons are relation-related by the school and the class' border of meaning. If the school and the teachers begin to accept the new media situation and begin to relate differently to time and space with regard to teaching, then the class, as a self-organising interaction system through its communication, will gradually build social structures and norms that are adequate for it. With measures such as abandoning prohibition and indifference and based on the new media situation with the open classroom, media-socio-evolution could take off from an adequate definition of the situation. We must then observe over time if the school class, seen as a social system, like the family and the workplace, with a porous membrane, can once again maintain itself with a renewed alliance with, or equilibrium relation to, the outside world pressure. If this evolves successfully, the school classes will be able to draw on all sorts of resources from all over the world in lessons, and have built in a structural indeterminacy in the education system, which conditioned by the teacher, would match the complexity of the outside world.

Thus our main finding in this article is that the teachers' more or less new role in the digital age is to bring relevant otherness through real-person-interaction in contact with the class on an everyday scale. Further it is to help the students to interact in educational valuable ways with this otherness. Through 
different normative concepts like Bildung it would be possible to develop new educational programs calibrating the class as an educational community with the surrounding world of otherness in progressive, democratic, sustainable and humanistic ways. Before the Internet the primary mode of learning was learning about the world outside the classroom (learning about other countries, for instance, giving rise to exotism and colonial thinking). In the digital age it becomes possible to form an educational setting, where the primary mode of learning becomes one in which students learn with and from other people outside the classroom on the basis of interaction. This is a radically new situation and possibility. To sum up, our argument is that all educational practises of the future and all educational theories, including normative philosophies of education, would benefit from adjusting to this new condition of educational possibilities, at least if they want to take adequately responsibility of the "new world" and the new generations being born into this world.

\section{References}

Andersen, N.Å. og N.T. Thygesen (2004). "Styringsteknologier i den selvudsatte organization", i Grus (25) 73 pp. 8-29.

Bourdieu, P (200o). "Cultural Reproduction and Social Reproduction” Pp. 56-68 in R. Arum and I. Beattie (Eds.) The Structure of Schooling: Readings in the Sociology of Education. London: McGraw-Hill Higher Education.

Bruns, A. (2008). Blogs, Wikipedia, Second Life and Beyond: From Production to Produsage. New York: Peter Lang.

Drejer, C. M. (2014). Kampen om eleven - Hvordan skoler skaber elever. København Unge Pædagoger.

Finnemann, N. O. (2005). Internettet i Mediehistorisk Perspektiv. Frederiksberg: Forlaget Samfundslitteratur.

Jenkins, H., Ford, S. and Green, J. (2013). Spreadable media - Creating value and meaning in a networked culture. New York: New York University Press.

Jenkins, H. (2008). Convergence Culture: Where old and new Media collide. New York: New York University Press.

Jenkins, H. et. al (2006) Confronting the Challenges of Participatory Culture: Media Education for the 21st Century. London: The MIT Press

Luhmann, N. (2007, [2002]): Indføring i systemteorien. København: Unge Pædagoger.

Luhmann, N. (2006 [2002].). Samfundets uddannelsessystem. København: Hans Reitzels Forlag.

Luhmann, Niklas. (2006b). Organisation und Entscheidung. 2. Auflage. Wiesbaden: Verlag für Sozialwissenschaften.

Luhmann, N. (200o). Familiarity, Confidence, Trust: Problems and Alternatives. In Gambetta, Diego (ed.) Trust: Making and Breaking Cooperative Relations. Oxford: Electronic edition, Department of Sociology, University of Oxford, chapter 6, pp. 94-107. 
Luhmann, N. 1999: Die Gesellschaft der Gesellschaft. Suhrkamp taschenbuch wissenschaft [1997].

Luhmann, N. (1995). Social Systems. Stanford University Press. California. [1984]

Luhmann, N. (1990). Political Theory in the Welfare State. Berlin : Walter de Gruyter, [1981/1987].

Luhmann, N. (1979). Trust and Power. John Wiley \& Sons Ltd. Vertrauen [1973], Macht [1975].

Meyrowitz, J. (1985). No Sense of Place: The Impact of Electronic Media on Social Behavior. New York: Oxford Uni. Press.

Paulsen, M. \& Tække, J. (2009). Om den uformelle (mis)brug af medier i det formelle uddannelsessystem. i Mediekultur vol 46, Journal of media and communication research. Retrived in: http://ojs.statsbiblioteket.dk/index.php/mediekultur/article/view/1331/1488

Paulsen, M. \& Tække, J. (2015b). Digital dannelse - Udfordringer, erfaringer og perspektiver fra Randers HF \& VUC. København: Unge Pædagoger.

Qvortrup, L. (2013). Den myndige læerer - Niklas Luhmanns blik på uddannelse og pæedagogik. København: Forlaget Dafolo.

Qvortrup, L. (1998). Den lærende organisation. I Billesø \& Baltzer, Pcedagogiske teorier, Værløse, pp. 201-226.

Tække, J. \& Paulsen, M. (2015a [in print]). Fæellesskab og Netvcerk - om sociale medier $i$ gymnasiet. København: Forlaget Unge Pædagoger.

Tække, J \& Paulsen, M. (2014). Hybridisation of Education : leaving the Echo room. Paper presented at Hybrids - Observed with Social Systems Theory, Dubrovnik, Kroatien.http://pure.au.dk/portal/files/74830460/Hybridisation of Education Taekke og Paulsen 2014.pdf

Tække, J \& Paulsen, M. (2013a). Sociale medier i gymnasiet - mellem forbud og ligegyldighed. København: Forlaget Unge Pædagoger.

Tække, J. \& Paulsen, M. (2013b). Social Media and the Hybridization of Education. in Cybernetics \& Human Knowing, 2013, 20 (1-2) - 141-158.

Tække, J. og Paulsen, M. (2013c). Social Media and Teaching - Education in the new media environment. Paper to the 4oth anniversary Nordmedia conference: Defending democracy. Oslo and Akershus University College, 8-11 August 2013.

Retrived: http://pure.au.dk/portal/files/54508198/Social Media and Teaching. Taekke and Paulsen.pdf

Tække, J. \& Paulsen, M. (2012). The challenge of social media - between prohibition and indifference in the classroom. Conference Paper for the Thirteenth Annual Convention of the Media Ecology Association: The Crossroads of the Word. 710 June 2012 Manhattan 
College Riverdale, New York, retrived:

http://pure.au.dk/portal/files/45108803/MEA 2012 Taekke.pdf

Tække, Jesper \& Paulsen, Michael (2010). Trådløse netværk og sociale normer. i Norsk Medietidsskrift 17, nr. 1, pp. 16 - 45.: http://www.idunn.no/ts/nmt/2010/o1/arto1

Tække, J. (2014). Mediet sprog som strukturel kobling : forudsætningen for Homo Cogitus Socius. i Systemteoretiske analyser: At anvende Luhmann. red. / Gorm Harste; Morten Knudsen. Frederiksberg : Nyt fra Samfundsvidenskaberne, 2014. s. 235-261.

Tække, J. (2011). Digital panopticism and organizational power. in Surveillance and Society, Vol. 8, Nr. 4, 2011, s. 441-454.

Retrived: http://pure.au.dk/portal/files/40242308/Digital panopticism and organizational power.pdf

Tække, J. (2011b). Media as the mechanism behind structural coupling and the evolution of the mind. Paper presented at LUHMANN IN ACTION: EMPIRICAL STUDIES OF STRUCTURAL COUPLINGS, International University Centre of post-graduate studies (IUC), Dubrovnik, Croatia.

Retrived: http://pure.au.dk/portal/files/35259305/Dubrovnik Taekke.pdf

\footnotetext{
' See Drejer (2014) for different pedagogies and discourses of discipline and Meyrowitz (1985: 78, 254, 258) for the influence of different media on education.

ii Here Luhmann also notes that "On this background arises further the question about how good the teacher is as a facilitator of the outside world when the world he was brought up in was completely different from his students" (Luhmann 2006: 131). This aspect must be considered to be more relevant now than ever before because of the new media environment.

iii Here we follow the mindset of Joshua Meyrowitz' epoch-making book "No Sense and Place" (Meyrowitz 1985).

iv We have documentation in various forms like thousand of tweets, observations, pictures and interviews (see Tække \& Paulsen 2013a).

$\checkmark$ The concept of power chain goes under the concept of decision premises for the late Luhmann (2006b).
} 